\title{
Poststructuralist-Feminist International Relations: A Point of Reconciliation?
}

\author{
Lailatul Fitriyah $^{1}$
}

\begin{abstract}
The relationships between peace studies and international relations (IR) has never been easy. The "strategic" nature of inter-state relations in IR and its state-centric focus are some of the big challenges to the humanitarian nature of peace studies. However, the rise of feminism in IR in the 1980s has given us a new promise in opening the field of IR to a greater humanitarian focus which could take even the individual level of analysis into account. IR poststructuralist-feminism - which is understood as an IR feminist perspective which deconstruct the "common assumptions of culture" (Sylvester, 1994) including feminism itself - is particularly progressive in the sense that it does not only provide the room to problematize the basic assumptions of mainstream IR, but also room to even question the premises of the IR feminists themselves, a self-reflective quality shared by contemporary peace studies.

One of the latest theoretical developments in poststructuralist-feminist IR is the "adoption" of positive psychology into IR methodology in order to take a deeper look into the mostly forgotten dimension of humans' capability to flourish even under the most extreme condition (Penttinen, 2013). Again, this new proposal resonates with the current trend in peace studies scholarship in which peacebuilding processes are geared toward fuller ownership by the locals and harnesses their capabilities to survive. This article would like to analyze the potentialities of feminist approaches in IR, particularly those which come from the poststructuralist school of thought, as a fruitful "meeting point" for peace studies and IR. Once we identify the "meeting point," hopefully it can bring us into a rich inter-disciplinary endeavor in the future as well as a better understanding of the dynamics of peacebuilding practices in the context of international relations.
\end{abstract}

Key Words: international relations, poststructuralist feminist IR, peace studies, positive psychology, reflective practices

\footnotetext{
${ }^{1}$ Nostra Aetate Fellow-Pontificium Consilium Pro Dialogo Inter Religiones, Rome-Italy and Master of Arts in International Peace Studies, Kroc Institute for International Peace Studies, University of Notre Dame, IndianaUSA. Untuk tujuan akademik penulis dapat dihubungi di email : lfitriya@alumni.nd.edu
} 
The peak of the Cold War in the mid-1980s has been regarded as the starting point of the institutionalization of peace research (Rogers and Ramsbotham, 1999, p.740; Mack, 1991, p.74) though the initiation of the field of study can be traced back to the failure to prevent the World War II in 1945 (Rogers and Ramsbotham, 1999, p.740) or even to the works of Pitirim Sorokin and Quincy Wright in the 1930s (Mack, 1991, p.74). And ever since the peace research enterprise started to build its foundations, it has been in contradictory position against the traditional understanding of realpolitik which then become the backbone of international relations as a field of study.

There are several dimensions in which peace studies and international relations are seem to be contradictory to each other. But the biggest part of it which dominated the early development of peace studies was concerned with methodology.
As a field of study that came out of the Cold War fear, peace studies was and is still partially done through quantitative methodology. This methodological differrence become the source of critiques from both camps to each other. The tradetionalists, which in here means the realists, of IR seen peace studies as a part of behavioralist revolution, and thus the peace studies scholars were on the other side of the traditionalist-behavioralist debate. While the peace studies scholars seen the realists as held up to unquestioned beliefs, unproven assumptions, and to be methodologically unsound (Rogers and Ramsbotham, 1999, p.740).

Basically, in the midst of Cold War environment the proponents of realism and the peace research scholars derived very different lessons (Mack, 1991, p.78). The realism-dominated IR took the view that the re-occurrence of war means that the international politics is ruled by the clashes 
of national interests where competing alliances is the only way for states to survive in the international arena. That 'peace' is only possible to be maintained by the military and arm rivalries between states. Meanwhile, the peace scholars see the rise of the nuclear age as the strategic limit of war. The existence of a military technology that can ensure the devastation of a country will render the practicality of war become obsolete (Mack, 1991, p.78). In the context where military war will not result in winning, the arrangement of collective security, where the physical security of a state depends on not only its own defensive capability but also on the cooperative actions of other states, is a much more rational option.

A closer look into the distinct characteristics of peace studies will reveal that the differences between peace studies and international relations is wider than just a methodology. Based on seven features of peace studies as written by Paul Rogers and Oliver Ramsbotham (1999), I identify seven differences between peace studies and international relations. First, peace studies has a big concern in addressing the root causes of violence while also preventing further violence to occur. On the other hand, the definition of 'peace' in realist IR is limited to the absence of armed violence between states. In the field of peace studies, these differences are expressed through the debate between 'minimalist' and 'maximalist' agenda (Rogers and Ramsbotham, 1999, p.741).

Second, the interdisciplinary nature of peace studies (Rogers and Ramsbotham, 1999 , p.741) is also something that become a point of friction between IR and peace studies. The traditional IR is rooted in the atomistic or mechanistic-deterministic worldview in which the efforts to comprehend the world is divided into natural sciences and social sciences (Penttinen, 
2013, p.10). That is why, the fact that peace studies brings a whole regimen of disciplines such as psychology, environmental studies, or even mathematics into the analysis of international conflict is something that IR cannot accept (Rogers and Ramsbotham, 1999, p.744).

Third, one of the main assumptions in peace studies, namely the search for nonviolent transformations to eliminate violent situations (Rogers and Ramsbotham, 1999, p.741), is in opposition with main assumption in traditional IR in which the struggle for national interests rules the dynamics of international politics. As Thomas Matyok suggested in his work, the goal of peace studies is not only to answer the question of "what it is?" or "why it is?", but also to question "what it can be?" (Matyok, 2011, p.xxv). In other words, peace studies not only tries to define what is "peace" or why does violence takes place, but also what are the probabilities for a peaceful future of human's civilization. While the goal of international relations is to make sense of what happens in the international politics with an underlying assumption that "human nature is inherently frail and bound by constricting conditions and want" (Penttinen, 2013, p.19).

Fourth, peace studies requires a multi-level analysis (Rogers and Ramsbotham, 1999, p.741) to understand the complex structure of conflict and to provide a prescriptive explanation on how to prevent the latter occurence of violence. This feature challenges the foundation of traditional IR that divides the conduct of politics into two categories, the domestic and international politics. The perspective on states as unitary-rational actors in the context of international politics leaves no roles for domestic politics to be relevant in the foreign-policy making process. This distinction is not applicable in peace studies. As Rogers and Ramsbotham mentioned in 
their work, peace studies takes the distinction between domestic and international politics, better known as the "internal" and "external" debate, as “artificial” (Rogers and Ramsbotham, 1999, p.748). This boundary is seen as "artificial" in the sense that the influence of local dynamics to global occurences cannot be prevented by the application of state's sovereignty anymore. And since the physical security of a state is not only depends on its defensive capacities, then the mere existence of a state as a means to reach the national interests is also inadequate because no states could possibly gain interests without the support, sacrifices, or compromises from others.

The fifth feature of peace studies that is in opposition with the traditional IR is the adoption of a global and multi-cultural approach (Rogers and Ramsbotham, 1999, p.741). The central tenet of realism in international relations is the homogenization of any particularities that exist within a society into the unitary presence of a state. This assumption is best expressed by Robert Jackson in his work, "Classical and Modern Thought on International Relations” (2005), "whatever is instrumental to the interests of the state is deemed to be just, because the good life is obtainable only within the orbit of the state." (Jackson, 2005, p.18). Thus, the presence of culture as a variable is something that the traditional IR cannot incorporate into its structure.

The sixth feature is the position of peace studies as an analytic and normative enterprise (Rogers and Ramsbotham, 1999, p.741). As what I have mentioned before, peace studies is not only aimed for an explanation for what is "peace" or why does violence takes place. More than that, for most of peace scholars it is an expression of their ideals of a better lives (Rogers and Ramsbotham, 1999, p.742). In the words of Matyok, peace studies introduces a new 
disciplinary definition called design knowing (what it can be) that is distinct from scientific knowing (what it is) or humanistic knowing (why it is) (Matyok, 2011, p.xxv). In the realist IR perspective, state is a unitary-rational actor that find itself in an anarchic international politics where it can only deal with each others "in terms of power, guided by their interests, ..., seeking to gain advantages or at least not to suffer disadvantages from their foreign relations, ... “ (Jackson, 2005, p.19). “A political virtue" in realist's perspective is understood as recognizing opportunities to maximize interests or prevent loss since the international politics takes place in an anarchic arena (Jackson, 2005, p.19).

The last feature of peace studies is the close relationship between theory and practice (Rogers and Ramsbotham, 1999, p.741). It means that much of the theories in the field of peace studies are informed by empirical findings. Peace studies emphasizes design knowing, it seeks for solutions through close analysis to the roots of the problem. On the other hand, international relations is built upon two main assumptions, first, that there is always someone else who will fix the problem, and second, that is analyzing the problem will somehow bring about a solution (Penttinen, 2013, p.14). However, the second assumption is secondary in the sense that the practice of scholarship in international relations is not built for finding solutions to the problem (Penttinen, 2013, p.14).

These differences seems to be an irreconcilable friction between peace studies and international relations. The focus of IR to the state actor and its main goal to make sense of international politics is not in line with peace studies's multi-level analysis and its goal to design knowing. However, leaving this gap unabridged is in contrary with the interdisciplinary feature of peace studies itself. It is also become a big hurdle 
to the development of international relations as a field of study. Penttinen specifically proposes that international relations scholarship has to be done in a way where the inquiries is not only resulted in scholarly abstractions that is disconnected from the world, but more than that, it has to be a practice that incorporate "the experience of flow and open-hearted positivity" (Penttinen, 2013, p.15). In a world where the non-state actors can possibly be stronger than a state and where the national boundaries is permeable, the way IR scholarship is done should be revisited.

\section{The Meeting Point}

The seemingly irreconcilable differences between peace studies and IR might be reconcilable after all, thanks to the poststructuralist feminist IR and the conflict transformation approach in peace studies. The birth of feminist perspective in IR begun in 1980s where the accumulation of feminist IR publications made the new perspective gathered a significant amount of attention and by 1990 there was a Feminist Theory and Gender Studies section (FTGS) at the International Studies Association (Sylvester, 2004, pp.8-9). However, echoing Tickner (1997) Sylvester believes that "a marriage of feminist ways of thinking and doing research with IR's positivism appears doomed." (Sylvester, 2004, p.12). Thus, in the context of international relations, Sylvester proposes a new international relations tradition where it would be possible for the feminist IR to theorize about people, places, authorities, and activities that the conventional IR could not accomodate (Sylvester, 2004, p.12).

In her description about poststructuralist feminism in IR, Christine Sylvester (1994) writes that poststructuralist/postmodernist feminist IR can be differentiated from standpoint feminism and feminist postmodernist by its function as a bridge between them (Sylvester, 1994, 
p.12). This negotiating position is characterized by poststructuralist feminist's conviction toward the importance of bringing women's voices to forth in IR while also staying in line with feminist postmodernist skepticisms (Sylvester, 1994,

p.12). Poststructuralist/postmodernist feminist IR opens a room for us to appreciate the strengths and limitations of our inherited identity without subsuming to the given stories that come with our identity or completely rejecting the identity because it comes from established authority sources (Sylvester, 1994, p.14). It probably best expressed by the question "how can we simultaneously put women at the center and decenter everything including women?" (Sylvester, 1994, p.12). This capacity to self-reflect will be one of the main features that bridges the relationship between peace studies and IR.

One of the methodological innovation that comes from the poststructuralist/postmodernist feminist IR is the methodology of joy that is introduced by Elina Penttinen in his book, "Joy and International Relations" (2013). In this book Penttinen proposes an alternative path to turns IR around from what she called as the ontology of problem-making, that is the "ontological assumption that there is something wrong in the world, that the world in itself is limited and needs to be fixed" (Penttinen, 2013, pp.11-12). This path, inspired by the field of positive psychology, tries to open the whole enterprise of IR to the mostly neglected experience of humanity, namely the "aliveness of matter and the inherent connectedness of the human as part of the world in its continuous becoming" (Penttinen, 2013, pp.10). Thus, in the context of feminist IR, the new methodology not only criticizes the traditional IR by exposing the importance of the women's voices in IR but also to question the features 
of the feminist IR itself, particularly the one which emphasizes the "ontology of human vulnerability and weaknesses and the idea that the world is an ontologically exploitative and oppressive place." (Penttinen, 2013, p.3).

The methodology of joy as proposed by Penttinen has five main components that are significantly different from traditional IR. First, it rejects the fragmented view and the classification of science into natural and social; second, it promotes the observation towards the potential of posthumanism and new materialism in the conceptualization of knowing and being; third, it introduces the alternative of the ontology of problemmaking, namely the studies on well-being and joy in places where suffering and trauma most commonly find; fourth, it emphasizes on the self-reflexivity which means that, first, it opens to questions about its own foundational beliefs, and second, that it understands the self as an intra-active part of the world which continuously becoming; and fifth, it understands the scholarship of international relations as a practice instead of an abstraction that is detached from the reality of the world (Penttinen, 2013, pp.13-14).

The radical move from the traditional practice of international relations which ignores the importance of selfreflection in doing IR scholarship, and from the common tendency in the feminist IR to focus only on the dimension of suffering and exploitation, lead the methodology of joy to be a meeting point between peace studies and international relations. A case that is particularly proven by two comparative characters between the methodology of joy in IR and the conflict transformation approach in peace studies. The first character is the focus on self-reflexivity, and the second character is the focus on the holistic experience of humanity. 
As what have been implied in the first part of the essay, just like international relations, peace studies is also the product of the bitterness of war. Thus the early period of peace studies is dominated by the conflict management school which aimed toward resolution of conflicts through diplomatic initiatives (Paffenholz, 2010, p.51). This school is pretty much limited in the sense that the capacity to forge peace is only owned by the state through their diplomats. The second school, known as the conflict resolution school, came up in 1970s and aims at analyzing the roots of conflicts and rebuild the relationships between conflicting parties (Paffenholz, 2010, p.52). It tries to expand conflict analysis on to societal level and incorporates strategies from sociopsychology as a means to engage the conflict at the interpersonal level.

The third school brings mostly new strategies in dealing with conflict, as well as operates from a completely different assumption than the ones used by both of schools. The conflict transformation school operates from the assumption that conflict is an inherent part in human's lives and thus irresolvable (Paffenholz, 2010, p.53). Rather than aims toward the resolutions of conflicts, this school tries to transform the destructive conflictual situation into a more constructive one. The most important element in this school is an acknowledgement for reconciliation potential within societies (Paffenholz, 2010, p.53). It means that the perspectives which subjectivated society to the third-party intervention is no longer relevant. Society is not only defined by their capacity to engage in conflict but also their capacity to actually forge peace. Individuals is not seen as unitary-rational actors who only cares about their interests, but also as holistic beings with innate capacities to live harmoniously. John Paul Lederach, one of the biggest proponents for conflict transformation 
school, writes that sustainable peace can only be achieved through intervention that does not impede the local initiatives (Lederach and Lederach, 2010, p.211).

The focus on local capacities to forge peace in peace studies and the focus on wellbeing and joy in the poststructuralist feminist IR function as the first meeting point from which both field of studies can gain a lot of advantages from the interdisciplinary endeavor. The second meeting point is located at the reflective practice that is also promoted by the conflict transformation approach and the methodology of joy in IR. Conflict transformation approach inquires evaluation that is not only design to measure the physical dimensions of peacebuilding processes but also to "asks practitioners to be more explicit about their assumptions, about what they are trying and why." (Lederach, 1997, p.134). This assumption is in line with the fourth and fifth features of methodology of joy which require scholars to question their fundamental beliefs in the process of making sense of the international politics. The importance of reflective practice in peacebuilding is at least proven with the message of "self-reflection" that become a buzzword in the MA program at the Kroc Institute for International Peace Studies, University of Notre Dame.

The tendency for both scholarships to come to a more inclusive and humanistic approach is something that we should be grateful about. The interdisciplinary features on both field of studies will open a broader vista which hopefully resulted in more comprehensive explanations on the nature of peace and war. The self-reflexivity that currently become a requirement for scholars in both fields will also contribute to the refinement of research results and theorybuilding process, in which scholars are no longer a value-free observer who only seeks to explain the phenomenon without any 
contribution to the design knowing. And most importantly, the development brings forth a more holistic picture of humanity in which human being is not only seen for their destructive quality but also for their innate tendency to harmony.

\section{References}

Jackson, R. (2005). Classical and Modern Thought on International Relations. New York: Palgrave Macmillan.

Lederach, J. P. (1997). Building Peace: Sustainable Reconciliation in Divided Societies. Washington, DC: United States Institute of Peace Press.

Lederach, J. P. , Lederach, A. J. (2010). When Blood and Bones Cry Out: Journeys Through the Soundscape of Healing and Reconciliation. Australia: Penguin Books.

Mack, A. (1991). Objectives and methods of peace research. In, T. Woodhouse (ed.), Peacemaking in a troubled world (73-106). New York: Berg Publishers.

Matyok, T. (2011). Designing a way forward: Why this book? Why now? In, T. Matyok, J. Senehi, \& S. Byrne (eds.), Critical issues in peace and conflict studies: theory, practice, and pedagogy (xxiii-xxviii). UK: Lexington Books.

Paffenholz, T. (2010). Civil Society and Peacebuilding: A Critical Assessment. Boulder, CO: Lynne Rienner Publishers.

Penttinen, E. (2013). Joy and International Relations: A New Methodology. New York: Routledge.

Rogers, P., Ramsbotham, O. (1999). Then and now: peace research - past and future. Political Studies, XLVII, 740754.

Sylvester, C. (1994). Feminist Theory and International Relations in $A$ 
Postmodern Era. Cambridge:

Cambridge University Press.

Sylvester, C. (2004). Feminist International

Relations: An Unfinished Journey.

Cambridge: Cambridge University

Press.

Tickner, J. A. (1997). You just don’t

understand: troubled engagements

between feminists and IR theorists.

International Studies Quarterly, 41,

$611-32$ 